\title{
PENGEMBANGAN KAPASITAS APARATUR PEMERINTAH DAERAH DI ERA OTONOMI (Studi Kasus: Pemerintah Daerah Kabupaten Samosir)
}

\author{
APPARATUS CAPACITY BUILDING OF \\ LOCAL GOVERNMENT IN THE ERA OF AUTONOMY \\ (Case Study: Local Government of Samosir Regency)
}

\author{
Yosep Ginting dan Sorni Paskah Daeli \\ Badan Penelitian dan Pengembangan Kementerian Dalam Negeri \\ Jalan Kramat Raya No.132 Jakarta Pusat \\ e-mail: joseph.ginting@ymail.com dan sornipaskah@yahoo.com
}

Diterima: 5 April 2012, Direvisi: 10 Mei 2012, Disetujui: 31 Mei 2012

\begin{abstract}
Abstrak
Penelitian ini dilakukan untuk memotret pengembangan kapasitas sumberdaya manusia aparatur di Kabupaten Samosir. Metode pendekatan yang digunakan adalah deskriptif kualitatif, dengan penggunaan data primer dan sekunder. Hasil penelitian menunjukkan kualitas sumberdaya manusia masih rendah, banyak jabatan struktural yang belum terisi, rekrutmen belum didasarkan pada analisis jabatan, evaluasi jabatan belum dilakukan, penilaian kinerja individu berdasarkan kompetensi belum dilakukan, serta sebagian besar pegawai belum mendapatkan diklat sesuai dengan jabatannya. Disarankan untuk melakukan penataan sistem rekrutmen; analisis jabatan; evaluasi jabatan; penyusunan standar kompetensi jabatan; penilaian individu berdasarkan kompetensi; pengembangan database pegawai; dan perbaikan kurikulum pendidikan dan pelatihan.
\end{abstract}

Kata Kunci: sumberdaya manusia, pengembangan, kapasitas.

\begin{abstract}
This research was conducted to capture the human resource capacity development of Samosir regency officials. The method used in this research is descriptive qualitative method, using the primary and secondary data. The results of the research demonstrates that the quality of human resources is still low, there are many positions in the organization structure are unfilled, the employee recruitment system is not based on job analysis, job position evaluation system have not been implemented, individual performance evaluation is not done according to competency based assessment, and employees have not received training according to their job position. It is recommended to perform system setup on recruitment; job analysis; Job evaluation; setting on job competency standard; competency based individual assessment; employee database development, and improvement on education and training curricula.
\end{abstract}

Keywords: human resource, development, capacity.

\section{PENDAHULUAN}

Sejalan dengan diterapkannya sistem desentralisasi, di mana pemerintah memberikan kewenangan yang besar kepada daerah untuk menyelenggarakan berbagai urusan pemerintahan, dilakukan berbagai upaya untuk mengembangkan kapasitas pemerintah daerah dalam penyelenggaraan urusan pemerintahan melalui pengembangan kapasitas sumberdaya manusia aparatur. Tujuannya adalah terciptanya pemerintahan daerah yang memiliki kapasitas yang berkelanjutan (sustainable) dalam penyelenggaraan pemerintahan, sehingga peningkatan kesejahteraan masyarakat dapat dicapai secara efektif dan efisien. Namun demikian, selama kurang lebih satu dasawarsa terakhir, upaya ini masih optimal guna mencapai hasil yang diharapkan.

Upaya pengembangan kapasitas sumberdaya manusia (SDM) aparatur ini masih belum dapat dikelola dengan baik. Hal itu ditunjukkan antara lain oleh, masih sulitnya mengubah cara pikir (mindset) dan cara kerja aparatur, masih rendahnya disiplin dan etika pegawai, sistem karier yang belum sepenuhnya berdasarkan prestasi kerja, sistem remunerasi yang belum memadai untuk hidup layak, rekrutmen yang belum dilakukan berdasarkan kualifikasi pendidikan yang dibutuhkan, penyelenggaraan pendidikan dan pelatihan (diklat) yang belum sepenuhnya dapat meningkatkan kinerja, lemahnya pengawasan dan audit terhadap kinerja aparatur, dan sistem informasi manajemen kepegawaian yang belum berfungsi secara optimal (BAPPENAS, 2007). Akibat dari berbagai persoalan tersebut adalah, pelaksanaan pelayanan publik yang efisien dan efektif, yaitu cepat, tepat, murah, dan transparan, belum dapat diwujudkan.

Siagian (1996) mengemukakan, bahwa rendahnya kinerja birokrasi disebabkan oleh 
beberapa sebab, seperti simpang siurnya perundangundangan yang mengatur bidang kepegawaian; merajalelanya 'spoil system' dalam penerimaan, pengangkatan, penempatan dan promosi pegawai; tidak adanya data statistik yang akurat tentang jumlah pegawai negeri yang menimbulkan kesukaran dalam kebijaksanan di bidang kepegawaian; sistem penilaian yang tidak obyektif; pendidikan dan pelatihan yang tidak terarah; banyaknya instansi yang turut campur tangan dalam memecahkan masalah kesejahteraan pegawai; dan pendapatan pegawai negeri yang rendah yang membawa implikasi pada rendahnya kegairahan kerja dan sukarnya menegakkan disiplin pegawai.

Oleh karena itu, dalam rangka meningkatkan kinerja pemerintah daerah, maka faktor pengembangan kapasitas aparatur menjadi sangat urgent. Di samping untuk merespon tingginya tuntutan masyarakat terhadap kinerja pemerintah daerah, pengembangan kapasitas (capacity building) SDM aparatur tidak bisa dilepaskan dengan keinginan pemerintah untuk menjalankan good governance yang diarahkan untuk mempraktekkan tata kelola pemerintahan yang ideal.

Salah satu isu sentral good governance, yaitu adanya perubahan kapasitas pemerintah dalam merespon dan memperjuangkan kepentingan kolektif masyarakat berdasarkan koridor institusi yang ada (Keban, 2011). Dengan demikian, dapat juga berarti bahwa good governance harus didukung oleh dua aspek utama, yaitu masyarakat dan negara. Aspek yang pertama direpresentasikan oleh dua arena, masyarakat sipil dan masyarakat ekonomi. Masyarakat sipil berarti bahwa semua warga negara berhak mengontrol penyelenggaraan yang dilakukan pemerintah. Sementara aspek yang kedua direpresentasikan oleh birokrasi dan lembaga politik (political office). Aspek inilah yang menjadi kerap menjadi sorotan, terutama mengenai birokrasi yang di dalamnya termasuk SDM aparatur.

Namun, pertanyaan pokok yang selalu muncul adalah, sampai seberapa besar keberhasilan pengembangan kapasitas aparatur itu di dalam mendukung reformasi birokrasi, khususnya di dalam pembangunan, pelaksanaan fungsi pemerintahan dan pemberian pelayanan publik. Faktanya dapat dilihat melalui media massa tentang kinerja pemerintahan yang selalu digambarkan sebagai ketidakmampuan, kelemahan, dan kejahatan dari berbagai pihak, mulai dari eksekutif, legislatif dan yudikatif.

Pengembangan kapasitas SDM aparatur merupakan program andalan reformasi birokrasi dan telah mulai dilaksanakan sejak Pemerintahan Orde Baru berakhir, namun belum banyak membawa pengaruh. Pelaksanaannya dilatar belakangi oleh berbagai faktor, di antaranya: tingginya praktek korupsi, kolusi dan nepotisme (KKN); tingkat kualitas pelayanan publik yang belum mampu memenuhi harapan publik; tingkat efisiensi, efektifitas dan produktivitas yang belum optimal; tingkat transparansi dan akuntabilitas yang masih rendah; serta tingkat disiplin dan etos kerja pegawai yang masih rendah.

Oleh karena itu, untuk percepatan pelaksanaan reformasi birokrasi di daerah, khususnya di Kabupaten Samosir, perlu penelitian mengenai potret SDM aparatur Pemda Kabupaten Samosir, agar dapat dirumuskan model pengembangan kapasitas SDM aparatur di daerah. Pemilihan Kabupaten Samosir sebagai lokus penelitian, karena kabupaten ini termasuk salah satu daerah otonomi hasil pemekaran yang relatif telah lama mandiri.

Penelitian terdahulu yang relevan dengan penelitian ini dilakukan oleh Siswanto (2006), dengan judul Studi Pengembangan Kapasitas Litbang Kesehatan di Daerah Provinsi Kalimantan Timur (Suatu Analisis Situasi). Penelitian ini bertujuan untuk melakukan analisis situasi dalam rangka mendapatkan base-line data tentang litbang di derah guna menyusun model pengembangan litbang di daerah dari aspek kelembagaan, SDM dan anggaran. Hasilnya, bahwa dari aspek kelembagaan, di propinsi sudah dibentuk Balitbangda, sementara di tingkat kabupaten/kota belum seluruhnya. Kemudian, dari aspek jumlah SDM fungsional peneliti dan penganggaran di Balitbangda propinsi dan kabupaten/kota sangat terbatas. Perbedaan penelitian ini dengan penelitian terdahulu tersebut adalah bahwa penelitian ini lebih spesifik pada aspek SDM dan ruang lingkupnya khusus di kabupaten. Oleh karena itu, penelitian ini merupakan pengembangan penelitian terdahulu.

\section{METODE PENELITIAN}

Metode penelitian ini adalah deskriptif kualitatif dengan tujuan untuk membuat gambaran secara sistematis, faktual dan akurat mengenai faktafakta dan sifat-sifat dan hubungan antara fenomena yang diselidiki. Data yang digunakan adalah data primer dari hasil wawancara yang melibatkan informan. Informan yang diwawancarai dalam penelitian ini adalah kalangan Pemerintah Daerah Kabupaten Samosir. Teknik snowball sampling juga digunakan ketika akses kesemua daftar informan yang diteliti tidak didapat. Jadi data yang digunakan adalah data kualitatif. Selain itu, ada data sekunder berupa dokumen resmi, laporan dan studi media juga digunakan. Selanjutnya, data yang diperoleh dianalisis secara teknik deskriptif kualitatif, yaitu dengan model interaktif dengan tahapan, yaitu melakukan reduksi data, sajian data dan penarikan kesimpulan.

\section{Pengembangan Kapasitas Aparatur Daerah}

Pengembangan kapasitas memiliki multi makna, dan interpretasinya tergantung pada siapa yang menggunakan dan dalam konteks apa. Secara umum, yang dipahami adalah bahwa pengembangan kapasitas merupakan suatu konsep yang terkait erat 
dengan pendidikan, pelatihan dan pengembangan sumberdaya manusia. Namun, pemahaman konvensional mengenai konsep pengembangan kapasitas telah berubah selama beberapa tahun terakhir, di mana pengembangan kapasitas dipahami secara lebih luas dan holistik, yang mencakup aspek sosial, organisasi dan pendidikan (Enemark, 2006).

UNDP menawarkan definisi dasar: "sebagai kemampuan individu dan organisasi atau unit organisasi untuk menjalankan fungsi-fungsinya secara efektif, efisien dan berkelanjutan". Definisi ini memiliki tiga aspek penting, yakni: (1) kapasitas bukan merupakan suatu keadaan pasif, tetapi merupakan bagian dari suatu proses yang berkelanjutan; (2) menekankan pada SDM dan bagaimana SDM tersebut didayagunakan; dan (3) konteks keseluruhan di mana organisasi melakukan fungsifungsinya merupakan pertimbangan kunci dalam strategi pengembangan kapasitas (Enemark, 2006).

World Bank menekankan perhatian capacity building pada: (1) pengembangan SDM; training, rekruitmen dan pemutusan pegawai profesional, manajerial dan teknis; (2) keorganisasian, yaitu pengaturan struktur, proses, sumberdaya dan gaya manajemen; (3) jaringan kerja (network), berupa koordinasi, aktifitas organisasi, fungsi network, serta interaksi formal dan informal; (4) lingkungan organisasi, yaitu aturan (rule) dan undang-undang (legislation) yang mengatur pelayanan publik, tanggung jawab dan kekuasaan antara lembaga, kebijakan yang menjadi hambatan bagi development tasks, serta dukungan keuangan dan anggaran; dan (5) lingkungan kegiatan lebih luas lainnya, meliputi faktor-faktor politik, ekonomi dan situasi-kondisi yang mempengaruhi kinerja (Edralin, 1997).

Selanjutnya, UNDP memfokuskan pada tiga dimensi, yakni: (1) tenaga kerja (human resources), menyangkut kualitas SDM dan cara SDM dimanfaatkan; (2) modal atau dimensi fisik, menyangkut sarana material, peralatan, bahan-bahan yang diperlukan dan ruang/gedung; dan (3) teknologi, menyangkut organisasi dan gaya manajemen, fungsi perencanaan, penentuan kebijakan, pengendalian dan evaluasi, komunikasi, serta sistem informasi manajemen (Edralin, 1997).

Menurut UNDP, kapasitas dipandang dari dua dimensi, yaitu kapasitas penilaian dan pengembangan kapasitas (Enemark, 2006). Kapasitas penilaian adalah dasar penting bagi perumusan strategi yang koheren bagi pengembangan kapasitas. Kapasitas penilaian merupakan proses dan analisis terstruktur, di mana berbagai dimensi kapasitas dinilai dalam konteks sistem yang lebih luas, sebagaimana suatu entitas atau individu tertentu di dalam suatu sistem dievaluasi. Adapun pengembangan kapasitas adalah suatu konsep yang lebih luas dari human resources development, karena ditekankan pada sistem secara keseluruhan, lingkungan dan konteks di mana individu, organisasi dan masyarakat beroperasi dan berinteraksi.
UNDP mengemukakan bahwa pengembangan kapasitas terjadi pada level sistem, organisasi dan individu (Enemark, 2006):

1. Tingkat sistem: di mana inisiatif pengembangan kapasitas dipandang sebagai suatu sistem pada tingkat lingkungan. Untuk inisiatif pembangunan yang berada pada konteks nasional, sistem akan mencakup seluruh negara atau masyarakat dan semua subkomponen yang terlibat. Untuk inisiatif di tingkat sektoral, sistem akan mencakup hanya komponen yang relevan. Dimensi-dimensi kapasitas pada tingkat ini dapat mencakup bidang-bidang seperti kebijakan, kerangka kerja hukum/ peraturan, perspektif manajemen dan akuntabilitas, dan sumberdaya yang tersedia.

2. Tingkat organisasi: suatu entitas mungkin saja merupakan organisasi formal seperti pemerintah atau salah satu instansi, sektor swasta, atau organisasi informal yang berbasis komunitas atau organisasi sukarela. Pada tingkat ini, pengembangan kapasitas mencakup peran dari entitas dalam sistem, dan interaksi dengan entitas lain, stakeholder, dan klien. Dimensi kapasitas dapat mencakup bidang-bidang seperti misi dan strategi, budaya dan kompetensi, proses, dan infrastruktur.

3. Tingkat individu: pada tingkat ini, pengembangan kapasitas dilakukan untuk membuat individu-individu dapat berperan secara efisien dan efektif, baik dalam entitasnya maupun dalam sistem yang lebih luas. Pengembangan SDM dilakukan dengan menilai kebutuhan masing-masing orang dan mengatasi kesenjangannya melalui kegiatan-kegiatan diklat secara berkelanjutan. Kapasitas penilaian dan pengembangan pada tingkat individu ini dianggap paling kritis. Karena itu, dimensi kapasitas harus mencakup desain program diklat untuk memenuhi kesenjangan yang teridentifikasi dengan basis keterampilan.

Pengembangan kapasitas dapat difokuskan pada tingkatan manapun dan dilaksanakan berdasarkan analisis yang mendalam terhadap seluruh dimensi yang relevan. Selain itu, pengembangan kapasitas harus dilihat sebagai metodologi yang komprehensif ditujukan untuk memberikan hasil yang berkelanjutan melalui menilai dan mengatasi berbagai macam masalah yang relevan dan hubungan mereka (Enemark, 2006).

Pengembangan kapasitas dalam konteks pemerintah dilakukan untuk mengembangkan suatu ragam strategi meningkatkan efficiency, effectiveness, dan responsiveness kinerja pemerintah, yakni efficiency, dalam hal waktu (time) dan sumberdaya (resources) yang dibutuhkan guna mencapai suatu outcome; effectiveness berupa kepantasan usaha yang dilakukan demi hasil yang diinginkan; dan responsiveness, yakni bagaimana menyinkronkan 


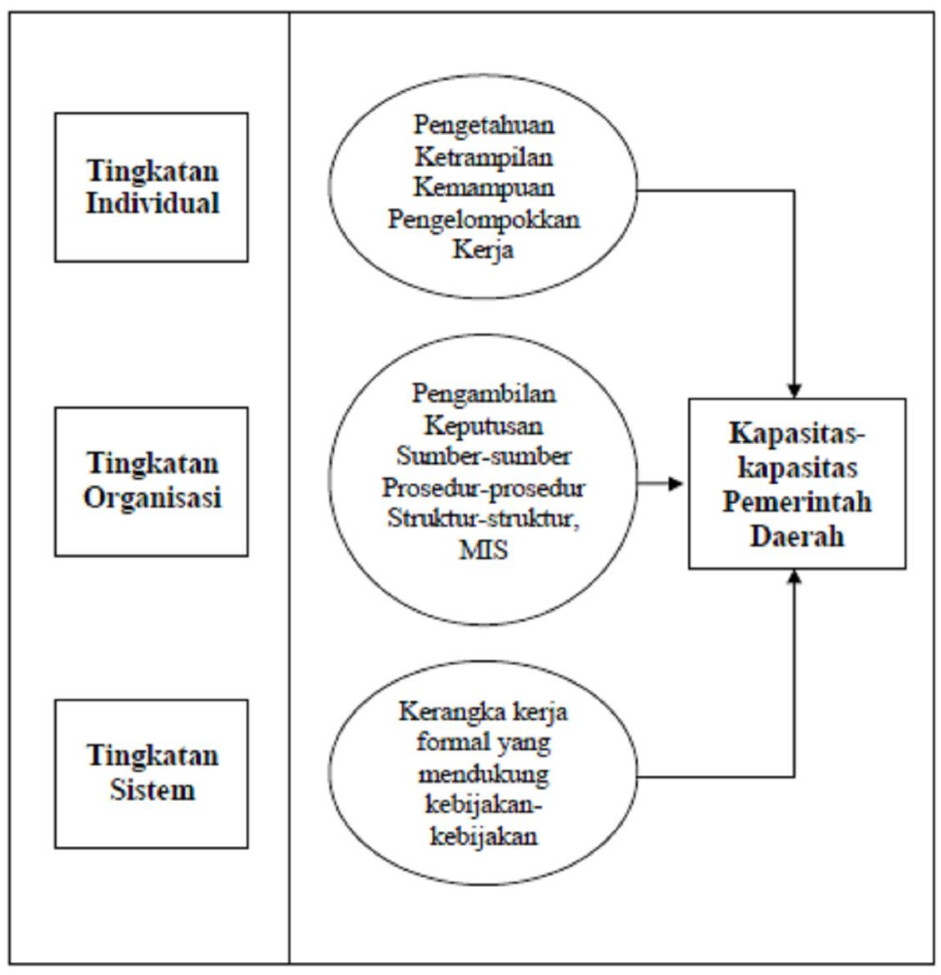

Gambar 1. Tingkat Pengembangan Aktivitas.

antara kebutuhan dan kemampuan untuk maksud tersebut. Hal itu sejalan dengan pendapat Merilee S. Grindle (1997) bahwa capacity building is intended to encompass a variety of strategies that have to do with increasing the efficiency, effectiveness, and responsiveness of government performance. Secara lebih spesifik, capacity building bagi penyelenggaraan pemerintahan didefinisikan oleh Finn \& Checksoway sebagai "sampai seberapa jauh staf mampu menunjukkan kontribusi yang nyata terhadap pengembangan personal, organisasi dan masyarakat" (Soeprapto, 2007).

Pengembangan kapasitas dalam pemerintahan sering dilakukan dengan memberikan caracara (tools) terbaik untuk membantu pemerintah dalam menjalankan tanggung jawabnya. Hal ini termasuk membangun kemampuan pemerintah dalam penyusunan anggaran, mengumpulkan pendapatan, membuat dan melaksanakan undangundang, mempromosikan keterlibatan masyarakat, membuat pengelolaan anggaran lebih transparan dan akuntabel, serta memerangi korupsi. Dalam konteks yang lebih sempit, pengembangan kapasitas Pemda mencakup upaya-upaya untuk menyesuaikan, mereformasi, dan memodifikasi seluruh kebijakan, peraturan, prosedur, mekanisme kerja, koordinasi; meningkatkan keterampilan dan kualifikasi aparatur Pemda; dan mengubah sistem nilai dan sikap yang dijadikan acuan aparatur Pemda, agar Pemda mampu menyelenggarakan tata pemerintahan yang demokratis dan menyejahterakan masyarakat.
Upaya-upaya tersebut disebut intervensi (Nurkholis, 2005).

Dengan demikian, sesuai dengan level pengembangan kapasitas sebagaimana dikemukakan oleh UNDP, maka pengembangan kapasitas Pemda mencakup tiga level intervensi, yaitu:

1. Level sistem: intervensi pada pengaturan kerangka kerja dan kebijakan dalam sistem pemerintahan daerah, sehingga dapat mendukung pencapaian tujuan yang diinginkan. Pengaturan kerangka kerja dan kebijakan harus berangkat dari konsepsi berdasarkan UndangUndang Nomor 32/2004 yang dioperasionalkan melalui peraturan pelaksanaan berupa PP dan peraturan teknis seperti Kepmen dan Inmen. Pada tingkat Daerah, Daerah menindaklanjuti dengan pembuatan Peraturan Daerah dan Peraturan Kepala Daerah.

2. Level kelembagaan: intervensi pada penataan struktur organisasi, proses pengambilan keputusan organisasi, prosedur dan mekanisme kerja, instrumen manajemen, dan hubungan dan jaringan antara organisasi yang satu dengan organisasi lainnya. Penataan struktur organisasi Pemda dikembangkan berdasarkan azas efektivitas dan efesiensi organisasi yang ditandai dengan bentuk organisasi yang ramping, datar, dan sesuai dengan kebutuhan. Proses pengambilan keputusan organisasi dikembangkan berdasarkan pada model pengambilan keputusan yang baik (pengumpulan data yang akurat, partisipatif, pengembangan alternatif secara 
cerdas, dan pemilihan satu alternatif terbaik). Pemda harus mengembangkan prosedur dan mekanisme kerja yang urut, runtut, logis, tidak tumpang tindih, mengarah pada satu titik/tujuan, dan tidak bolak-balik dengan standar yang terukur. Pemda harus mengembangkan instrumen manajemen berupa pedoman kerja, peralatan, sarana dan prasarana sabagai fasilitasi untuk mencapai tujuan. Hal yang tak kalah pentingnya adalah perlunya mengembangkan sistem koordinasi antara satu unit dengan unit lainnya.

3. Level individual: intervensi pada peningkatan kualitas individu aparatur Pemda, agar memiliki keterampilan, pengetahuan, sikap, etika, dan motivasi kerja, sehingga berkemampuan menyelenggarakan tata kepemerintahan yang baik (good governance). SDM aparatur Pemda harus dilatih dengan keterampilan sesuai bidangnya sehingga menjadi kompeten (Nurkholis, 2005).

Pengembangan kapasitas melalui intervensi pada level sistem, institusi, dan individu merupakan upaya yang multidimensi. Oleh karena itu, perencanaannya harus ditetapkan dalam tahapan waktu yang rasional: jangka pendek, jangka menengah, dan jangka panjang. Selanjutnya, pada setiap tahapan harus ditetapkan prioritasprioritasnya. Prioritas pertama dari semua tahapan tersebut adalah membuat kebijakan dan peraturan pendukung, yakni penjabaran operasional dari framework otonomi daerah berdasarkan UndangUndang Nomor 32/2004 dan Undang-Undang Nomor 33/2004 yang wujudnya adalah penyesuaian dan modifikasi semua perangkat peraturan perundangan organik berupa kebijakan Daerah seperti Perda dan Keputusan Kepala Daerah, yang dapat menciptakan sistem yang efektif dan efisien untuk mencapai tujuan. Semua kebijakan dan peraturan tersebut harus jelas menggambarkan sistem dan mekanisme prosedural yang melibatkan semua level tersebut. Prioritas berikutnya adalah menangani permasalahan yang terjadi dalam hubungan antar unit dan antar sektor.

\section{Pengembangan Kapasitas SDM Aparatur Pemda} Amstrong (2006) mengatakan bahwa SDM adalah harta yang paling penting bagi suatu organisasi. Karena itu, SDM harus mendapatkan perhatian yang serius agar sasaran organisasi dapat tercapai. Salah satu sasaran yang dapat digunakan oleh para manajer dalam rangka melaksanakan investasi terhadap SDM di dalam organisasi adalah dengan melakukan pengembangan terhadap kapasitas SDM tersebut. Menurut Notoatmojo (dalam Suryanto, 2006), pengembangan SDM aparatur sangat penting, karena dapat meningkatkan kemampuan aparatur, baik kemampuan professionalnya, wawasannya, kepemimpinannya maupun pengabdiannya, sehingga pada akhirnya akan meningkatkan kinerja organisasi.

Tuntutan yang terasa kuat untuk melakukan pengembangan SDM, khususnya pada organisasi pemerintah disebabkan oleh: (1) tingkat pengetahuan dan kemampuan SDM masih relatif rendah; (2) suasana kerja yang kurang menyenangkan atau adanya kejenuhan karena terlalu lama bekerja pada suatu tempat; (3) adanya tuntutan organisasi terhadap perubahan; dan (4) perkembangan zaman yang sangat pesat (Amri, Suryono \& Suwondo, 2009). Senada dengan itu, Siagian (1996), menyatakan beberapa alasan utama perlunya pengembangan SDM, yakni: (1) adanya pegawai baru yang tidak mempunyai kemampuan secara penuh untuk melaksanakan tugasnya; (2) pengetahuan pegawai yang perlu pemuktakhiran; (3) perubahan, tidak hanya karena perkembangan ilmu pengetahuan dan teknologi, akan tetapi juga karena pergeseran nilainilai sosial budaya; dan (4) kemungkinan perpindahan pegawai.

Schuler dan Youngblood (Eade, 1998) mengungkapkan bahwa pengembangan SDM aparatur pada suatu organisasi akan mencakup berbagai faktor, seperti diklat, perencanaan dan manajemen karir, peningkatan kualitas dan produktivitas kerja, serta peningkatan kesehatan dan keamanan kerja. Sementara itu, Ivancevich (2002) memasukkan pula faktor motivasi kerja dan penilaian prestasi kerja sebagai aspek yang tercakup dalam pengembangan SDM aparatur. Di lain pihak, Osborne dan Gaebler (dalam Eade, 1998) lebih mementingkan pengembangan visi aparat pemerintah dalam memberikan pelayanan kepada publik. Hal itu sejalan dengan desentralisasi, pengembangan SDM aparatur yang perlu diarahkan pada pembentukan visi, inovasi, dan kemampuan aparat untuk melaksanakan semangat wirausaha dalam pelaksanana tugas mereka.

Selanjutnya CIDA (Canadian International Development Agency, Enemark, 2006) menyatakan, bahwa pengembangan SDM aparatur menekankan manusia sebagai alat maupun tujuan akhir pembangunan. Dalam jangka pendek, hal itu dapat diartikan sebagai pengembangan pendidikan dan pelatihan untuk memenuhi kebutuhan tenaga teknis, kepemimpinan, dan tenaga administrasi sesegera mungkin. Upaya ini ditujukan pada kelompok sasaran tertentu, yakni mereka yang terlibat dalam sistem sosial-ekonomi di negara tersebut. Pada sisi lain, Emmeriji (Calquit, 2006) merumuskan bahwa pengembangan SDM aparatur merupakan tindakan: (1) Kreasi SDM; (2) Pengembangannya; dan (3) Menyusun struktur insentif atau upah sesuai dengan peluang kerja yang ada. Ketiga tindakan tersebut mengandung makna bahwa untuk meningkatkan SDM aparatur yang berkualitas harus dilakukan melalui pendidikan formal dan pelatihan serta pemanfaatan sumberdaya tersebut. 
Di sisi lain, Luthans (2002) menyebutkan ada 8 (delapan) tujuan pengembangan SDM aparatur, yaitu: (1) Produktivitas personil organisasi (productivity); (2) Kualitas produk organisasi (quality); (3) Perencanaan SDM (human resources planning); (4) Semangat personil dan iklim organisasi (morale); (5) Meningkatkan kompensasi secara tidak langsung (indirect compensation); (6) Kesehatan dan keselamatan kerja (health and safety); (7) Pencegahan merosotnya kemampuan personil (absolerence prevention); dan (8) Pertumbuhan kemampuan personil (personal growth).

Steward (Calquit, 2006) mengatakan bahwa modal intelektual merupakan kekayaan organisasi, karena modal intelektual adalah muatan intelektual yang dimiliki pegawai, yang berupa pengetahuan, informasi, hak pemilihan intelektual, pengalaman yang dapat digunakan untuk menciptakan kekayaan. Untuk membangun sumberdaya aparatur yang berkualitas yang dapat dijadikan modal intelektual bagi organisasi, diperlukan upaya yang sistematis, berkelanjutan dan komprehensif. Upaya tersebut tidak hanya dilakukan melalui pendidikan formal yang diikuti oleh anggota organisasi, tapi juga didukung iklim organisasi yang kondusif. Hal ini karena modal intelektual harus dibangun melalui suatu tradisi ilmiah, dengan dukungan politik yang kuat dari para pengambil keputusan.

Membangun SDM aparatur yang berkualitas agar dapat menjadi modal intelektual organisasi, dapat dilakukan melalui penciptaan suatu organisasi pembelajaran (learning organization). Di dalam organisasi pembelajaran yang perlu dikembangkan adalah membiasakan setiap anggota organisasi berpikir secara sistematik, tidak berpikir secara individual ataupun terkotak-kotak. Sebab pada dasarnya setiap anggota organisasi memiliki tujuan yang sama yaitu mencapai tujuan organisasi (Millen, 2006).

Pada hakikatnya pengembangan SDM aparatur adalah memberikan motivasi kepada para pegawai, baik secara ekstrinsik maupun instrinsik, sehingga mereka dapat merasakan kepuasan kerja di lingkungan kerjanya. Motivasi tersebut diharapkan merupakan insentif yang mampu menggerakkan perilaku mereka untuk mencapai tujuan yang telah ditetapkan. Menurut Hersey and Blanchard (1999), penyelenggaraan tugas pekerjaan administrasi negara yang semakin luas dan rumit menuntut kemampuan dan kemauan (ability and willingness) orang-orang untuk memikul tanggung jawab untuk mengarahkan perilaku mereka sendiri. Bahkan Hersey dan Blanchard mengemukakan paling tidak terdapat tiga keterampilan yang perlu dimiliki setiap pegawai, sehingga proses manajemen, termasuk di birokrasi dapat berlangsung secara rasional, efektif, dan efisien, yakni: keterampilan teknik, keterampilan kemanusiaan, dan keterampilan konseptual. Sedangkan Vroom (Luthans, 2002) membuat rumusan $\mathrm{P}=\mathrm{C}$ $\mathrm{x} \mathrm{M}$, yang artinya pelaksanaan tugas pekerjaan yang dapat memberikan buah hasil yang bermanfaat $(\mathrm{P}=$ performance) hanya dapat dijamin apabila didukung oleh kemampuan $(\mathrm{C}=$ competence $)$ dan kemauan $(\mathrm{M}=$ motivation $)$ yang memadai. Dengan demikian, pandangan Vroom memperkuat dan menjelaskan pendapat Hersey and Blanchard.

Berdasarkan pandangan-pandangan di atas, dapat dikatakan bahwa pengembangan SDM aparatur dilakukan untuk menciptakan aparatur yang memiliki profesionalisme, yakni aparatur yang memiliki karakteristik: (1) Seseorang yang memiliki keterampilan dan keahlian teoritis ilmiah tertentu sesuai dengan bidang pekerjaan yang akan digelutinya; (2) Mampu menyumbangkan ilmu dan tenaganya secara optimal untuk kelancaran usaha tempat kerjanya; (3) Dapat mendorong peningkatan produktivitas yang berkelanjutan; (4) Memiliki sikap untuk terus menerus memperbaiki dan meningkatkan keahlian dan keterampilannya; (5) Disiplin dan patuh aturan profesionalisme dan tempat kerjanya; dan (6) Memiliki kesiapan untuk berubah atau melakukan penyesuaian terhadap perubahan-perubahan yang tengah berlangsung atau bahkan mampu menciptakan perubahan (Handayaningrat, 1995).

Pengembangan merupakan alat utama untuk menyesuaikan antara tugas dan pekerjaan dengan kemampuan, ketrampilan dan kecakapan serta keahlian dari setiap pegawai. Pengembangan juga merupakan faktor yang harus diselenggarakan dalam administrasi kepegawaian modern dan merupakan usaha untuk meningkatkan kinerja pegawai agar lebih cakap, trampil dan memahami dengan jelas tugas yang harus dilakukannya sesuai dengan kedudukannya sebagai seorang administrator.

Program-program pengembangan SDM yang diimplementasikan dalam bentuk off dan on the job misalnya tidak dilakukan dengan benar dan terkesan hanya sekedar menghabiskan anggaran yang tersedia, akibatnya dapat diduga bahwa peningkatan skill, knowledge dan ability sebagai tujuan utama yang harus diraih menjadi terdistorsi. Dengan demikian, kebijakan penyiapan SDM aparatur yang memiliki kinerja akan berkaitan dengan jenis dan sifat pengembangan yang akan dilakukan untuk memenuhi kebutuhan aparatur yang berkualitas.

\section{HASIL DAN PEMBAHASAN}

Berdasarkan data lapangan, jumlah pegawai di Kabupaten Samosir adalah sebanyak 3.787 orang, yang terdiri dari 1.481 laki-laki dan 2.306 perempuan. Komposisi pegawai berdasarkan kelompok umur di Kabupaten Samosir dapat dilihat pada Tabel 1 .

Berdasarkan Tabel 1 dapat dilihat bahwa komposisi pegawai berdasarkan kelompok umur di Kabupaten Samosir menunjukkan bahwa jumlah pegawai yang paling banyak adalah pegawai yang berusia antara 30-39 tahun (30,84 persen) dan usia 40-49 tahun (26,80 persen), sedangkan yang paling 
Tabel 1. Komposisi Pegawai Berdasarkan Kelompok Umur

\begin{tabular}{ccrrr}
\hline No. & Kelompok Umur & Laki-laki & Perempuan & \multicolumn{1}{c}{ Jumlah } \\
\hline 1. & $20-29$ tahun & 211 & 505 & 716 \\
2. & $30-39$ tahun & 480 & 688 & 1.168 \\
3. & $40-49$ tahun & 361 & 654 & 1.015 \\
4. & $>50$ tahun & 429 & 459 & 888 \\
& TOTAL & 1.481 & 2.306 & 3.787 \\
\hline
\end{tabular}

Sumber: Badan Kepagawaian Daerah, Kab.Samosir, 2012.

Tabel 2. Komposisi Pegawai Berdasarkan Tingkat Pendidikan

\begin{tabular}{|c|c|c|c|c|}
\hline No. & Tingkat Pendidikan & Laki-laki & Perempuan & Jumlah \\
\hline 1. & Sekolah Dasar & 15 & 0 & 15 \\
\hline 2. & Sekolah Lanjutan Pertama & 31 & 5 & 36 \\
\hline 3. & Sekolah Lanjutan Atas & 448 & 809 & 1.257 \\
\hline 4. & Diploma I & 12 & 37 & 49 \\
\hline 5. & Diploma II & 122 & 270 & 392 \\
\hline 6. & Diploma III & 176 & 513 & 689 \\
\hline 7. & Sarjana S1 & 660 & 663 & 1.323 \\
\hline 8. & Sarjana S2 & 20 & 6 & 26 \\
\hline 9. & Sarjana S3 & 0 & 0 & 0 \\
\hline & TOTAL & 1.481 & 2.306 & 3.787 \\
\hline
\end{tabular}

Sumber: Badan Kepagawaian Daerah, Kab.Samosir, 2012.

Tabel 3. Komposisi Pegawai Berdasarkan Golongan

\begin{tabular}{clr}
\hline No. & \multicolumn{1}{c}{ Golongan } & Jumlah \\
\hline 1. & Golongan Ia-Id & 29 \\
2. & Golongan IIa-IId & 1.295 \\
3. & Golongan IIIa-IIId & 1.524 \\
4. & Golongan IVa-IVe & 939 \\
& & TOTAL \\
\hline
\end{tabular}

Sumber: Badan Kepagawaian Daerah, Kab.Samosir, 2012.

sedikit adalah pegawai yang berusia $>50$ tahun (23,45 persen) dan antara 20-29 tahun (18,91 persen). Dari tabel tersebut juga terlihat bahwa pada seluruh kelompok umur pegawai jumlah pegawai perempuan lebih banyak dibandingkan dengan jumlah pegawai laki-laki, yakni 60,89 persen berbanding 39,11 persen.

Sedangkan berdasarkan tingkat pendidikannya, komposisi pegawai di Kabupaten Samosir dapat dilihat pada Tabel 2. Berdasarkan tabel di atas, dari aspek pendidikannya, pegawai di Kabupaten Samosir paling banyak berpendidikan setingkat sarjana, yakni 1.323 orang $(34,94$ persen) dan SLTA sebanyak 1.257 orang (33,19 persen). Jumlah pegawai yang berpendidikan SLTA ke bawah adalah sebanyak 1.308 orang, sedangkan pegawai dengan pendidikan SLTA ke atas adalah sebanyak 2.474 orang. Masih terdapat pegawai yang berpendidikan setingkat SD dan SLTP di Kabupaten Samosir, yakni sebanyak 51 orang (1,35 persen), sedangkan jumlah pegawai yang berpendidikan pasca sarjana masih sangat sedikit, yakni 26 orang $(0,69$ persen).

Dari Tabel 3 di atas, terlihat bahwa pegawai yang paling banyak adalah pada pegawai golongan III, yakni sebanyak 1.524 orang (40,24 persen), kemudian golongan II sebanyak 1.295 orang $(34,20$ persen). Sedangkan pegawai golongan IV ada sebanyak 939 orang (24,80 persen).

Informasi lainnya, berdasarkan pengisian jabatan struktural, dari 3.797 orang pegawai, sebanyak 933 orang $(24,64$ persen $)$ di antaranya menduduki jabatan struktural antara eselon IIa hingga eselon IVb. selanjutnya, dari 30 jabatan eselon II, baru sebanyak 25 jabatan yang telah diisi, sedangkan 5 jabatan lainnya belum terisi. Dari 25 jabatan yang telah diisi tersebut, 15 orang yang pejabatnya telah mengikuti Diklat PIM II, sedangkan 5 pejabat lainnya belum. Pada jabatan tingkat eselon III, dari 130 jabatan yang tersedia, 116 jabatan di antaranya telah diisi, sedangkan 14 jabatan lainnya masih belum terisi. Dari 116 jabatan yang terisi tersebut, baru 48 orang yang telah mengikuti Diklat PIM III, sedangkan 68 orang lainnya belum. Pada tingkat eselon IV, dari 471 jabatan yang tersedia, baru terisi 236 jabatan, sedangkan 235 jabatan belum terisi. Dari 236 jabatan yang terisi, yang pejabatnya telah mengikuti Diklat PIM IV baru sebanyak 65 orang, sedangkan 171 orang belum.

Dari wawancara dengan pejabat di Sekretariat Daerah Kabupaten Samosir, tingkat 
pendidikan pegawai yang ada saat ini dipandang mampu untuk mendukung pencapaian tupoksi organisasi perangkat daerah secara maksimal. Namun demikian, dilihat dari keseimbangan jabatan, yaitu antara jabatan struktural, fungsional khusus dan fungsional umum, belum seimbang, karena perbandingan jabatan fungsional umum dibandingkan dengan jabatan fungsional khusus masih jauh. Dalam rangka pengembangan kapasitas pegawai, Pemda telah melaksanakan berbagai program diklat pegawai (baik struktural maupun fungsional) sesuai dengan kebutuhan pegawai, meskipun pelaksanaan diklat tersebut masih belum optimal, padahal diklat pegawai tersebut dinilai memberikan dukungan yang tinggi terhadap kemampuan dan kinerja pegawai.

Dari sisi golongan/kepangkatan, tingkat keseimbangan pangkat/golongan pegawai menunjukkan komposisi pegawai di Kabupaten Samosir lebih banyak golongan III. Namun pangkat/golongan pegawai tersebut dipandang telah mencerminkan kapasitas pegawai, sebab dalam perekrutan pegawai disesuaikan dengan tingkat pendidikan dan jabatan. Kemudian, dari sisi keseimbangan gender, antara jumlah pegawai laki-laki dengan perempuan masih belum berimbang, karena jumlah pegawai perempuan lebih banyak dari jumlah pegawai lakilaki. Adapun dari komposisi pegawai berdasarkan kelompok umur dipandang cukup seimbang, karena perekrutan pegawai telah dimulai sejak tahun 2005.

Selanjutnya, dari kompetensi, kompetensi pegawai yang ada dipandang telah sesuai dengan tuntutan kinerja organisasi. Hal ini karena penerimaan pegawai dilakukan berdasarkan kebutuhan dan kualifikasi pendidikan yang sesuai dengan kompetensi. Sistem rekrutmen pegawai yang dilaksanakan dengan sistem pelamaran umum, pengangkatan tenaga honorer yang masuk database, dan mutasi pegawai dari daerah lain. Namun demikian, rekrutmen pegawai yang dilakukan belum didasarkan pada hasil analisis jabatan pada organisasi perangkat daerah, karena memang hingga saat ini belum pernah dilaksanakan analisis jabatan. Demikian pula, pemerintah daerah belum pernah melakukan evaluasi jabatan maupun penyusunan standar kompetensi jabatan pada organisasi perangkat daerah.

Dari aspek penilaian kinerja, hingga saat ini belum dlaksanakan penilaian individu berdasarkan kompetensi. Yang dilaksanakan adalah psikotest bagi pejabat eselon II dan III, sedangkan sistem penilaian kinerja individu belum diterapkan. Di samping itu, sedang dilakukan pembangunan database pegawai melalui penerapan sistem aplikasi pengelola kepegawaian (SPAK). Pengembangan diklat pegawai berbasis kompetensi telah dilakukan, namun belum optimal. Upaya-upaya yang telah dilakukan untuk pengembangan kapasitas SDM aparatur Pemda adalah diklat fungsional, diklat teknis dan diklat penjenjangan.
Fakta di atas mengindikasikan bahwa di Pemda Kabupaten Samosir masih terdapat banyak permasalahan mengenai pengembangan SDM aparatur, yakni Pertama, masih banyak pegawai di daerah yang tingkat pendidikannya masih rendah, dalam hal ini setingkat SLTA ke bawah. Di sisi lain, meskipun sebagian ada pegawai yang sudah berpendidikan sarjana, namun jumlah pegawai berpendidikan pasca sarjana masih sangat minim dibandingkan dengan total jumlah pegawai. Kedua, ada kecenderungan jumlah pegawai usia produktif (20-40 tahun) tidak lebih banyak dibandingkan dengan pegawai usia mendekati non produktif (40 tahun ke atas). Ketiga, tingkat pendidikan pegawai belum mampu mendukung pencapaian tupoksi secara maksimal, karena pembagian tugas belum dilakukan berdasarkan tingkat dan latar belakang pendidikan. Keempat, banyak jabatan struktural yang masih kosong atau belum terisi. Hal ini di samping terkait dengan kapasitas pegawai, juga terkait dengan masih belum adanya program diklat pegawai (baik struktural maupun fungsional) yang dilaksanakan selama ini untuk mengatasi kebutuhan pegawai secara keseluruhan. Kelima, dari sisi kompetensi, pegawai yang ada saat ini belum sesuai dengan tuntutan kinerja organisasi. Usia, tingkat pendidikan, dan pangkat/golongan ternyata belum mencerminkan kompetensi pegawai. Keenam, sistem rekrutmen meskipun cukup baik, namun belum mampu menjaring pegawai yang lebih berkualitas, sehingga menghasilkan personil yang lebih memiliki kapabilitas. Ketujuh, rekrutmen pegawai belum didasarkan pada analisis jabatan dalam organisasi guna untuk mendukung tercapainya tupoksi. Kedelapan, evaluasi jabatan dalam organisasi perangkat daerah belum dilakukan. Demikian pula, penyusunan standar kompetensi jabatan belum dilakukan untuk mendapatkan individu yang sesuai dengan kualifikasi dari jabatan tersebut. Kesembilan, penilaian kinerja individu berdasarkan kompetensi belum dilakukan. Kesepuluh, pengembangan database pegawai meskipun sudah dilakukan, namun belum mampu sepenuhnya menghasilkan informasi yang cepat, tepat, dan akurat. Kesebelas, pengembangan pendidikan dan pelatihan pegawai berbasis kompetensi, masih belum mampu meningkatkan kemampuan individu aparatur pemerintah secara maksimal sesuai dengan tuntutan pekerjaan. Keduabelas, pegawai-pegawai yang memiliki jabatan struktural maupun fungsional sebagian besar masih belum pernah mendapatkan diklat yang sesuai dengan jabatannya.

Temuan tersebut menunjukkan bahwa meskipun manajemen pembinaan pegawai di Kabupaten Samosir pada umumnya telah merujuk pada Undang-Undang Nomor 43/1999 beserta peraturan pelaksanaannya, namun implementasi Undang-Undang tersebut di lapangan mengindikasikan berbagai permasalahan yang kompleks sejak dari peraturan perundang-undangan hingga ke 
pengelolaan pegawai. Dari perspektif sistem, sistem kebijakan dan peraturan perundang-undangan tentang manajemen PNS selama ini sudah cukup baik, namun yang menjadi penyebab kurang profesionalnya pegawai adalah pada implementasi peraturan perundang-undangan tersebut. Misalnya, pada promosi dan mutasi pegawai yang seharusnya dilakukan secara transparan sebagai bentuk penghargaan dan tour of duty, dalam kenyataannya sering dilakukan secara sembunyi-sembunyi dan bermuatan politis. Pengaturan manajemen pegawai daerah dalam Undang-Undang Nomor 32/2004 dinilai bernuansa sentralisasi. Selain itu, di tataran pemerintah sendiri, koordinasi mengenai penetapan formasi PNS masih lemah. Peraturan tentang penggajian juga dinilai memiliki kelemahan karena gaji yang diberikan kepada pegawai sekarang ini kurang mampu memenuhi kebutuhan hidup layak, di samping itu, pemberian gaji hanya didasarkan pada golongan/pangkat dan masa kerja serta tidak mempertimbangkan kinerja yang dicapai oleh pegawai. Pejabat pembina kepegawaian yang dijabat oleh kepala daerah yang merupakan pejabat politis, sewaktu-waktu dapat menimbulkan permasalahan bagi pegawai, karena secara tidak langsung sering terkait dengan isu-isu politik.

Persoalan lain, aturan-aturan yang terdapat dalam PP Nomor 54/2010 tentang Disiplin PNS, ternyata sangat longgar dalam law enforcement-nya. Pertama, aturan hukum ini mengatur kehidupan PNS termasuk yang tidak berkaitan langsung dengan pelaksanaan tugasnya. Kedua, pelanggaran disiplin terlalu diakomodir dan hukuman yang diberikan sangat lunak. Ketiga, dalam praktiknya aturan-aturan dalam tersebut seringkali tidak berjalan secara efektif di lapangan baik, disebabkan oleh individu PNS itu yang tidak mematuhi peraturan tersebut maupun oleh pimpinan yang tidak tegas menegakkan aturan.

Masalah lainnya, PNS yang akan mengikuti suatu diklat tidak didasarkan pada training needs assessment (TNA) untuk mengetahui competency gap. Desain kurikulum dan program diklat yang diikuti oleh PNS harus mampu memperkecil competency gap. Dalam hal ini, pendekatan diklat merupakan competence-besed training. Namun dalam kenyataannya, tidak semua lembaga diklat PNS yang mengikuti pendekatan atau metoda ini. Bahkan pengiriman PNS ke suatu diklat dalam rangka menduduki jabatan sering terjadi tidak terkait dengan pengembangan kariernya. Hal ini tentu sangat boros sebagai akibat diabaikannya TNA.

Secara lebih mikro, permasalahan pengembangan kapasitas SDM aparatur daerah menyangkut seluruh sistem manajemen SDM, mulai dari perencanaan, pengadaan, sampai pensiun. Dari sisi perencanaan, hingga saat ini di daerah belum terdapat perencanaan kebutuhan pegawai yang jelas dan rinci. Khususnya Pemda Kabupaten Samosir belum memiliki peta kebutuhan pegawai (semacam manpower planning), paling tidak untuk lima tahun ke depan. Dalam proses rekrutmen selama ini, Pemda mengajukan usulan kebutuhan pegawai ke pemerintah pusat, namun belum melakukan penghitungan terhadap beban kerja dan kualifikasi pegawai yang dibutuhkan. Perencanaan kebutuhan pegawai hanya didasarkan pada usulan yang diajukan oleh masing-masing unit kerja kepada bagian kepegawaian untuk diteruskan oleh Bupati/Walikota ke pemerintah untuk mendapatkan formasi. Perencanaan seperti ini hanya bersifat jangka pendek, sehingga tidak dapat memetakan kebutuhan secara komprehensif terhadap kebutuhan pegawai baik kualifikasi pendidikan, keahlian, jumlah, distribusi dan kriteria-kriteria lain sesuai kebutuhan pembangunan dan visi/misi daerah. Ketiadaan perencanaan kebutuhan inilah antara lain menyebabkan terjadinya kelebihan jumlah pegawai. Ironisnya, sekalipun disadari bahwa jumlah pegawai yang ada dinilai telah berlebih, tetapi penambahan jumlah pegawai tetap terjadi, termasuk dari jalur dari tenaga honorer daerah.

Permasalahan lain, rekrutmen saat ini dilakukan oleh Pemda dan mendapatkan tekanan dari sejumlah pihak yang mempunyai kepentingan pribadi, sehingga pelaksanaannya tidak bebas dari KKN. Di samping itu, sistem rekrutmen juga tertutup dan bersifat kedaerahan, sehingga hanya orang-orang yang berasal dari daerah yang bersangkutan yang diajukan untuk dijadikan pegawai. Sistem ini terbentuk karena pada saat rekrutmen, persyaratan diarahkan agar hanya dapat diikuti oleh masyarakat di daerah tersebut.

Dari sisi beban kerja, secara umum beban kerja mayoritas pegawai belum optimal, karena porsi pekerjaan yang diselesaikan oleh pegawai masih berada di bawah kapasitas optimal yang seharusnya. Terdapat "pengangguran tidak kentara", karena beban kerja pegawai yang tidak sepadan dengan jumlah pegawai yang ada. Akibatnya, pekerjaan yang seharusnya dapat dilakukan oleh dua atau tiga orang, kenyataannya dilakukan secara gotong royong oleh empat orang atau lebih. Di sisi lain, pegawai yang good performer ini biasanya 'dipakai' oleh pimpinan, sedangkan yang bad performer cenderung kurang dipercaya untuk menyelesaikan pekerjaanpekerjaan yang membutuhkan keseriusan dan komptensi tertentu. Akibatnya, kelompok ini akan mengalami under employment, sehingga 'luntanglantung' di unit kerjanya. Beban kerja pegawai yang tidak seimbang ini pada dasarnya disebabkan oleh tidak tersedianya job description pada saat mereka diterima menjadi calon pegawai.

Dari sisi pola karier, sampai saat ini, di Pemda Kabupaten Samosir belum ada peraturan yang mengatur tentang pola karier pegawai. Padahal pola karier pegawai sangat penting sebagai dasar pengembangan karier dan potensi pegawai, sehingga pengangkatan pegawai dalam suatu jabatan struktural dapat dilakukan secara adil dan transparan. Jika pola karier telah terwujud, maka seorang pegawai dapat 
mengetahui arah, perjalanan dan bahkan merencanakan kariernya serta jabatan yang akan diembannya sesuai kompetensi yang dimiliki selama jangka waktu tertentu. Kondisi pola karier di Pemda Kabupaten Samosir, saat ini belum didasarkan pada standar kompetensi, baik persyaratan umum, persyaratan manajerial, dan persyaratan teknis, sehingga berdampak negatif terhadap kinerja Pemda. Sistem kenaikan pangkat yang diberlakukan selama ini masih bersifat administratif dan belum dikaitkan dengan prestasi kerja yang dihasilkan pegawai. Penyebab lainnya adalah, kelemahan sistem pengukuran kinerja, sehingga pegawai yang berprestasi kurang mendapat perhatian dan penghargaan yang adil. Pegawai yang prestasi kerjanya tidak bagus masih memungkinkan untuk naik pangkat/golongan. Kemudian, ada juga ketidaksesuaian antara kompetensi dengan pekerjaan yang diemban, karena pada saat rekrutmen, kebutuhan yang diinginkan oleh Pemda tidak sesuai dengan ketersediaan yang ada di masyarakat. Hal lainnya, pengembangan jabatan fungsional masih diabaikan oleh Pemda, padahal melalui jabatan fungsional dapat dikembangkan profesionalisme SDM aparatur.

Persoalan-persoalan di atas kemudian ditambah dengan persoalan mutasi-promosi pegawai dalam jabatan struktural yang sangat kental dengan nuansa politik lokal. Dari sisi promosi, promosi pegawai ke dalam jabatan struktural belum didasarkan pada kinerja pegawai yang bersangkutan. Promosi pejabat struktural masih dilakukan dengan cara 'dukung-mendukung'. Fenomena ini muncul karena besarnya otoritas kepala daerah dalam pengelolaan kepegawaian di daerah. Fungsi Badan Pertimbangan Jabatan dan Kepangkatan (Baperjakat) kurang efektif, karena Ketua Baperjakat dijabat langsung oleh Bupati Kabupaten Samosir. Dengan demikian, kepentingan politis sering mendominasi proses promosi pejabat struktural. Akibatnya, sangat sulit memperoleh pejabat struktural yang kompeten dan profesional di bidangnya, karena tujuannya hanya untuk melayani kepala daerah.

Dari sisi mutasi, terdapat permasalahan mengenai obyektivitas dalam penempatan pegawai sesuai dengan kompetensi pegawai. Pemda Kabupaten Samosir belum melakukan tes kelayakan dan kepatutan (fit and proper test) dalam rangka penempatan pegawai. Proses mutasi khususnya dalam pengertian perpindahan pegawai antar unit kerja di lingkungan Pemda Kabupaten Samosir, juga memperlihatkan kondisi yang belum terpola dengan mekanisme yang jelas, adil dan transparan, sesuai dengan kapasitas individual pegawai dan karakteristik, beban dan volume pekerjaan. Hasilnya, dapat dikatakan bahwa prinsip 'the right man in the right place on the right time' masih sebatas slogan, karena adanya muatan kepentingan tertentu.

Dari sisi pengukuran kinerja, sistem dan implementasi pengukuran kinerja pegawai sangat strategis, karena pada dasarnya hasil pengukuran kinerja yang dilakukan secara objektif, valid dan terukur memberikan banyak manfaat bagi proses pengambilan keputusan di bidang kepegawaian. Namun, hal ini kurang disadari oleh Pemda Kabupaten Samosir, di mana penilaian pegawai yang berlaku sampai saat ini pada dasarnya tidak memiliki arti yang nyata terhadap pengukuran kinerja pegawai. Penilaian sangat subyektif karena kelemahan-kelemahan aspek, mekanisme dan sifat pengukurannya. Hasil penilaian tersebut tidak dapat membedakan pegawai berkinerja bagus dengan yang tidak. Anehnya, tidak ada satupun dari atasan yang berkeinginan untuk memberikan penilaian yang jelek terhadap anak buahnya sekalipun faktanya memang kinerja bawahannya tidak memuaskan.

Dari sisi penggajian, pada semua tingkatan masih belum mampu membuat kesejahteraan bagi SDM aparatur. Persoalan minimnya gaji yang diterima selama ini, menjadi alasan klasik belum mampunya pegawai menunjukkan kinerja yang tinggi. Sebagian pegawai di Pemda Kabupaten Samosir masih mencari pendapatan tambahan di luar gaji yang diterimanya, dan banyak yang melaksanakan pekerjaan sampingan itu pada saat jam kantor.

Kemudian dari sisi diklat, beberapa kelemahan pola diklat yang dilaksanakan oleh Pemda Kabupaten Samosir antara lain: (1) Sistem diklat yang ada baru terfokus pada diklat penjenjangan, diklat fungsional dan diklat teknis, di mana itupun belum tertangani dengan baik dan masih dalam taraf perbaikan menyeluruh; (2) Training needs belum dapat dimanfaatkan untuk menghasilkan pola diklat yang sistemik dan berbasis kompetensi; (3) Desain diklat, kurikulum dan jam pelatihan belum mengacu pada standar kompetensi yang dibutuhkan; (4) Spesialisasi instruktur dan widyaiswara masih terfokus pada aspek manajemen; dan (5) Belum mempertimbangkan kesesuaian antara kompetensi pegawai dengan kompetensi jabatan yang akan datang. Untuk itu perlu disiapkan pola diklat yang dapat mendukung pola karir pegawai.

Di samping itu, pelaksanaan diklat selama ini sangat monoton, terutama dari segi substansi atau materi diklat. Sebagian besar materi Diklatpim Tingkat IV dan Diklatpim Tingkat III hampir sama. Di lingkungan Pemda Kabupaten Samosir, keterbatasan anggaran merupakan salah satu kendala utama dalam penyelenggaraan diklat PNS. Oleh karena itu, agar lebih efektif, maka peserta sebaiknya duduk dulu dalam jabatan yang baru, sebelum mengikuti Diklatpim.

\section{SIMPULAN}

Dari uraian di atas, potret SDM aparatur di Pemda Kabupaten Samosir adalah masih berkualitas rendah, banyak jabatan struktural yang belum terisi, rekrutmen pegawai belum berdasarkan pada analisis 
jabatan, evaluasi jabatan belum dilakukan, penilaian kinerja individu berdasarkan kompetensi belum dilakukan, dan kurikulum diklat belum mampu meningkatkan kemampuan sesuai dengan tuntutan pekerjaan.

Oleh karena itu, perlu penataan sistem rekrutmen pegawai; analisis jabatan; evaluasi jabatan; penyusunan standar kompetensi jabatan; penilaian individu berdasarkan kompetensi; pembangunan database pegawai; dan perbaikan kurikulum diklat.

\section{DAFTAR PUSTAKA}

Amri, Agus Suryono dan Suwondo. 2009. Pengembangan Sumberdaya Aparatur Sebagai Upaya Meningkatkan Kinerja: Studi di Kantor Sekretariat Daerah Kabupaten Sumbawa, WACANA, Vol. 12 No.3 Juli 2009.

Armstrong, Michael. 2006. A Handbook of Human Resource Management Practice, London, Philadelphia: Kogan Page.

Colquit, Jason A., Jeffery A. LePine \& Michael J. Wesson. 2009. Organizational Behavior: Improving Performance and Commitmen in the Workplace, New York: McGraw-HillIrwin.

Eade, D. 1998, Capacity Building: An Approach to People-Centered Development, Oxford, UK: Oxfam, GB.

Edralin, J.Sl. 1997. The New Local Governance and Capacity Building: A Strategic Approach, Regional Development Studies, Vol.3, p.148150.

Enemark, Stig. 2006. Capacity Building for Institutional Development in Surveying and Land Management, paper presented in the Promoting Land Administration and Good Governance, 5th FIG Regional Conference Accra, Ghana, March 8-11, 2006.

Hanif, Nurcholis. 2005. Pengembangan Kapasitas Pemda: Upaya Mewujudkan Pemda yang Menyejahterakan Masyarakat, Jurnal Organisasi dan Manajemen, Voume. 1, Nomor 1, September 2005.

Hersey, P. and K. H. Blanchard. 1999. Leadership and the One Minute Manager, New York: William Morrow.

Ivancevich, John M. and Michael T. Matteson. 2002. Organizational Bahavior and Management, Boston: McGraw-Hill.

Keban, Yeremias T. 2011, Мепији Sistem Ketatalaksanaan Pemerintahan Yang Baik, bahan presentase pada Diklatpim I Angkatan XXII LAN RI, 30 September 2011.

Luthans, Fred. 2002. Organizational Behavior, Boston: McGraw-Hill-Irwin.

Milen A. 2006. Capacity Building: Meningkatkan Kinerja Sektor Publik. Yogyakarta: Pembaruan.

Siagian, Sondang P. 1996. Manajemen Sumber Daya Manusia, Jakarta: CV. Haji Masagung.
Siswanto. 2006. Studi Pengembangan Kapasitas Litbang Kesehatan di Daerah Provinsi Kalimantan Timur (Suatu Analisis Situasi), Laporan Penelitian Balitbang Depkes, Jakarta.

Soeprapto, Riyadi. 2007. Pengembangan Kapasitas Pemerintah Daerah Menuju Good Governance, Jakarta: PT Gunung Agung.

Suryanto. 2006. Reformasi Kebijakan Pelaksanaan Administrasi Pemerintahan Daerah, Jurnal Desentralisasi Vol. 7 No.4 Tahun 2006.

http://www.bappenas.go.id/get-file-server/node/ 6167/ diunduh tanggal 14 Agustus 2012. 
